\title{
Patterns of development in the creekbank region of a barrier island Spartina alterniflora marsh
}

\author{
Anna Christina Tyler*, Joseph C. Zieman \\ Department of Environmental Sciences, University of Virginia, Charlottesville, Virginia 22903, USA
}

\begin{abstract}
Physical factors, such as local geomorphology and hydrology, are the primary determinants of biological pattern and process in a salt marsh. The increased topographic relief associated with the creekbank region is thought to control the unique chemistry and productivity found there. This study was designed to examine the role that tidal creeks play during the natural development of a barrier island Spartina alterniflora marsh ecosystem on the Eastern Shore of Virginia, USA. A salt marsh chronosequence, resulting from a 1962 overwash event, was used as a 'space-for-time' substitution in order to define the changes that take place within this marsh over a successional time scale. The chronosequence of marshes is largely attributed to the variation in elevation across the overwash platform: younger marshes are higher relative to sea level. We used a principal components analysis on a suite of physico-chemical and biological variables. A single principle component explained $53 \%$ of the variability in the data and is used to describe the functional trajectory along which these marshes develop. This component is associated with an increase in sediment organic matter and nitrogen content $(\% \mathrm{~N})$, porewater nutrients, $S$. alterniflora height, weight, \%flowering and $\% \mathrm{~N}$, and a decrease in grain size and redox potential. The factor scores from this analysis, which were used as a proxy for the functional maturity of the marsh, increased from creek edge to interior marsh for young marsh sites. Thus, the marsh nearest the creek most resembles the mature marsh. The temporal patterns of creekwater physico-chemistry vary between different aged creeks, suggesting that due to their small size and shallow depth younger creeks act to retain nutrients and particulates within the marsh. The hydrological, chemical and biological processes within the creeks themselves and at the creekbank are important in controlling the overall rate of marsh development. While creeks act to accelerate the rate of maturation, our results also indicate that not all marshes follow the same developmental trajectory and that the regional landscape may be a more important factor. With the increased interest in marsh restoration and creation for the mitigation of coastal wetland loss, there is a need for a greater functional understanding of the factors that control marsh development. The results of this study suggest that increasing creek frontage will increase the rate at which created marshes achieve functional equivalence with mature marshes.
\end{abstract}

KEY WORDS: Salt marsh · Barrier island - Tidal creek · Succession · Chronosequence $\cdot$ Spartina

\section{INTRODUCTION}

In recent years, the creation and restoration of coastal wetlands has increased, and there is an even greater need for an understanding of natural marsh development in order to assure the success of these restoration projects. Indeed, one of the greatest needs in wetland mitigation projects is a better understanding of wetland function (Mitsch \& Wilson 1996) and the

·E-mail: tyler@virginia.edu relationship between physical factors, such as geomorphology and hydrology, and marsh development (Haltiner et al. 1997). Although the function of mature marshes has been addressed in scientific research for many decades, the function of natural salt marshes during the early stages of development has not been as fully addressed. Knowledge of the factors controlling the natural development of marshes will further understanding of how these systems can be preserved, restored and created.

Salt marshes are physically driven systems (Mitsch \& Gosselink 1993). In such systems, the landscape dic- 
tates the hydrology, which in turn controls the chemistry and biota. As biotic feedbacks are weak relative to the main physical driving forces, it follows that the developmental trajectory of salt marshes is controlled to a great extent by physical forces. Because of the unique geomorphology of the creekbank region, we predict the development of this zone to proceed along a different trajectory and at a different rate than the interior marsh. Tall form Spartina alterniflora is generally associated with the creekbank; this relationship has been attributed to the increased porewater movement in this region (Wiegert et al. 1983). Increased flushing has, in turn, been linked to several environmental factors which are thought to control $S$. alterniflora growth, including increased sediment aeration (Agosta 1985), increased nutrient supply (Valiela et al. 1978, Osgood et al. 1995, Osgood \& Zieman 1998), decreased salinity (Phleger 1971) and decreased sulfide concentration (King et al. 1982). The steady-state relationship between the tidal creek and some biotic, geochemical, and hydrological processes has been described, the geomorphological evolution of tidal creek networks has been extensively studied (e.g. Pestrong 1965, Garofalo 1980, French \& Stoddart 1992, Knighton et al. 1992, Shi et al. 1995), and the relationship between tidal creeks and marsh utilization by macrofauna has been established (Minello et al. 1994). However, the relationship between the tidal creek and the physico-chemical development of the vegetated portion of the marsh has not been examined previously.

Traditional models of natural marsh development based on the classification set out by Chapman (1960) have described the developmental trajectories of 'transgressive', 'degrading', or 'Mudge' marshes, where a rise in sea level causes the invasion of low marsh vegetation into the high marsh (e.g. Dame et al. 1992, Childers et al. 1993, Dame \& Gardner 1993, Brinson et al. 1995), and 'prograding', 'Shaler' marshes, where increasing sediment deposition causes the gradual transformation of low marsh into high marsh (e.g. Redfield 1972, Frey \& Basan 1978, de Leeuw et al. 1993). A third type of development, as described by de Leeuw et al. (1993), occurs on island marshes, where the geomorphology of the initial sand platform dictates the development. This type of development is analogous to the development of artificially created marshes and the barrier island overwash marshes described in the present study, where a new sediment surface is established within the intertidal zone. Regardless of the developmental trajectory, the broad patterns of species distribution in a salt marsh are determined primarily by the elevation of the sediment surface relative to sea level (Frey \& Basan 1978, Bertness 1991, Gray 1992).
In the low marshes of the Atlantic Coast of the United States, salt marsh cord grass Spartina alterniflora grows predominantly in monospecific stands. This species is both the pioneer and the climax species unless there is a change in the relative positions of the sediment surface and sea level. In a study of marsh succession in The Netherlands, Roozen \& Westhoff (1985) found that the species composition in the low marsh, although comprised of different species than in the U.S., remained more or less constant over time, while there was a predictable change in species composition higher in the intertidal zone. The dominance of $S$. alterniflora throughout low marsh maturation prohibits the use of changes in species composition to characterize stages in marsh development. Therefore, low marsh development must be defined by changes in other parameters. Physico-chemical properties have been used to describe developmental changes in a variety of ecosystems for nearly a century (Cowles 1901, Olson 1958). It has also been suggested that developmental patterns may be characterized more adequately by organismal or physiological parameters rather than by changes in species composition (Shelford 1911, Drury \& Nisbet 1973).

Previous research in both naturally developing and restored salt marshes has shown that the developmental trends during the early stages of marsh development ( $<50 \mathrm{yr}$ ) are somewhat predictable, despite the fact that there is little change in the species composition. Table 1 is a summary of some of the past research that has been done in naturally developing, restored and created marshes. This list is not meant to be an exhaustive survey of marsh development and has been limited to studies of early marsh development on newly established substrate. Because there have been so few studies of primary succession in naturally developing marshes, the list is dominated by studies in created or artificial marshes.

The majority of the studies cited in Table 1 were conducted in created or restored marshes and have compared created marsh properties with those of a mature 'reference' marsh in order to establish a 'functional equivalency trajectory' of marsh development (Brinson \& Rheinhardt 1996, Simenstad \& Thom 1996, Piehler et al. 1998). Despite problems with choosing the appropriate reference marsh (Brinson \& Rheinhardt 1996) and the extreme variability present in natural marshes (Simenstad \& Thom 1996), natural reference marshes delimit the 'end-point' of developmental processes and can aid in an assessment of the time necessary for nascent marshes to reach functional maturity. These studies have illustrated that (1) different functional attributes reach mature levels at different times and (2) the developmental trajectories depend on the initial conditions. For example, in transplanted marshes in 
Table 1. Summary of some of the past work on developmental trends in marshes. The different types of trends listed are: $\Uparrow$ increase, $\Downarrow$ decrease, $\varnothing$ no distinct trend. The types of marshes are: $C$, created, $N$, natural

\begin{tabular}{|c|c|c|c|c|}
\hline Parameter & Trend & Location & Type & Sources \\
\hline \multicolumn{5}{|l|}{ Biota } \\
\hline \multirow[t]{8}{*}{ Vascular plant biomass } & $\Uparrow$ & N. Carolina & $\mathrm{C}$ & $\begin{array}{l}\text { Cammen (1976a), Seneca et al. (1976), Broome et al. (1986), } \\
\text { Piehler et al. (1998) }\end{array}$ \\
\hline & $\Uparrow$ & S. California & $\mathrm{C}$ & Langis et al. $(1991)$ \\
\hline & $\Uparrow$ & Virginia & $\mathrm{N}$ & Walsh (1998) \\
\hline & $\varnothing$ & Washington & $\mathrm{C}$ & Simenstad \& Thom (1996) \\
\hline & $\Uparrow$ & Virginia & $\mathrm{C}$ & Havens et al. (1995) \\
\hline & $\Downarrow$ & Virginia & $N$ & Osgood \& Zieman (1993a) \\
\hline & $\Uparrow$ & Massachusetts & $\mathrm{N}$ & Redfield (1972) \\
\hline & $\Uparrow$ & England & C & Underwood (1997) \\
\hline \multirow{2}{*}{ Vascular plant $\% \mathrm{~N}$} & $\Uparrow$ & S. California & $\mathrm{C}$ & Langis et al. (1991) \\
\hline & $\Downarrow$ & Virginia & $\mathrm{N}$ & Osgood \& Zieman (1993a) \\
\hline \multirow[t]{4}{*}{ Microalgae (chl a) } & $\Uparrow$ & England & $N$ & Bames et al. (1976) \\
\hline & $\Uparrow$ & Washington & $\mathrm{C}$ & Simenstad \& Thom (1996) \\
\hline & $\Uparrow$ & England & $\mathrm{C}$ & Underwood (1997) \\
\hline & $\Uparrow$ & N. Carolina & $\mathrm{C}$ & Piehler et al. (1998) \\
\hline \multirow[t]{3}{*}{ Infaunal density } & $\varnothing$ & England & $N$ & Barnes et al. (1976) \\
\hline & $\Uparrow$ & Texas & $\mathrm{C}$ & Minello \& Zimmerman (1992) \\
\hline & $\Uparrow$ & N. Carolina & $\mathrm{C}$ & Sacco et al. (1994) \\
\hline \multirow[t]{3}{*}{ Epifaunal density } & $\Uparrow$ & Virginia & $\mathrm{N}$ & Walsh (1998) \\
\hline & $\Uparrow$ & N. Carolina & $\mathrm{C}$ & Moy \& Levin (1991), Levin et al. (1996) \\
\hline & $\Uparrow$ & Washington & $\mathrm{C}$ & Simenstad \& Thom (1996) \\
\hline \multirow[t]{3}{*}{ Fish utilization } & $\Uparrow$ & Texas & $\mathrm{C}$ & Minello \& Zimmerman (1992), Minello \& Webb (1997) \\
\hline & $\Uparrow$ & Washington & $\mathrm{C}$ & Simenstad \& Thom (1996) \\
\hline & $\Uparrow$ & California & $\mathrm{C}$ & Haltiner et al. (1997) \\
\hline \multirow[t]{3}{*}{ Bird utilization } & $\Uparrow$ & Virginia & $\mathrm{C}$ & Havens et al. (1995) \\
\hline & $\Uparrow$ & Washington & $\mathrm{C}$ & Simenstad \& Thom (1996) \\
\hline & $\Uparrow$ & Texas & $\mathrm{C}$ & Melvin \& Webb (1998) \\
\hline \multicolumn{5}{|l|}{ Substrate } \\
\hline \multirow[t]{5}{*}{ Grain size } & $\Downarrow$ & Massachusetts & $\mathrm{N}$ & Redfield (1972) \\
\hline & $\Downarrow$ & England & $\mathrm{N}$ & Barnes et al. (1976) \\
\hline & $\Downarrow$ & Virginia & $\mathrm{N}$ & Osgood \& Zieman $(1993 a, b)$, Walsh (1998) \\
\hline & $\varnothing$ & Washington & $\mathrm{C}$ & Simenstad \& Thom (1996) \\
\hline & $\varnothing$ & N. Carolina & $\mathrm{C}$ & Cammen $(1976 \mathrm{a}, \mathrm{b})$ \\
\hline Permeability & $\Uparrow$ & England & $\mathrm{N}$ & Barnes et al. (1976) \\
\hline \multicolumn{5}{|l|}{ Biogeochemistry } \\
\hline \multirow{8}{*}{ Organic content } & $\Uparrow$ & England & $\mathrm{N}$ & Barnes et al. (1976) \\
\hline & II & Virginia & $\mathrm{N}$ & Osgood \& Zieman $(1993 a, b)$, Walsh (1998) \\
\hline & $\Uparrow$ & N. Carolina & $\mathrm{C}$ & $\begin{array}{l}\text { Cammen (1976a), Seneca et al. (1976), Craft et al. (1988), } \\
\text { Sacco et al. (1994). Piehler et al. (1998) }\end{array}$ \\
\hline & $\Uparrow$ & Texas & $C$ & Lindau \& Hossner (1981) \\
\hline & $\Uparrow$ & S. California & $c$ & Langis et al. (1991) \\
\hline & $\Uparrow$ & Texas & $\mathrm{C}$ & Minello \& Zimmerman (1992) \\
\hline & $\Uparrow$ & Virginia & $\mathrm{C}$ & Havens et al. (1995) \\
\hline & $\varnothing$ & Washington & $\mathrm{C}$ & Simenstad \& Thom (1996) \\
\hline \multirow[t]{4}{*}{ Nutrient reservoirs } & $\Uparrow$ & N. Carolina & $\mathrm{C}$ & Craft et al. (1988), Thompson et al. (1995) \\
\hline & $\Uparrow$ & Virginia & $\mathrm{N}$ & Osgood \& Zieman (1993a,b), Walsh (1998) \\
\hline & $\pi$ & S. California & $\mathrm{C}$ & Langis et al. (1991) \\
\hline & $\Uparrow$ & Texas & $\mathrm{C}$ & Lindau \& Hossner (1981) \\
\hline \multirow[t]{3}{*}{ Redox potential } & $\Downarrow$ & Virginia & $N$ & Osgood \& Zieman (1993a,b), Walsh (1998) \\
\hline & \& & S. California & $\mathrm{C}$ & Langis et al. (1991) \\
\hline & $\Downarrow$ & N. Carolina & $\mathrm{C}$ & Thompson et al. (1995) \\
\hline \multirow{3}{*}{$\begin{array}{l}\text { Denitrification } \\
N \text { fixation }\end{array}$} & $\Uparrow$ & N. Carolina & C & Thompson et al. (1995) \\
\hline & $\hat{\Uparrow}$ & S. California & $\mathrm{C}$ & Langis et al. (1991) \\
\hline & से & N. Carolina & $\mathrm{C}$ & Currin et al. (1996), Currin \& Paerl (1998), Piehler et al. (1998) \\
\hline
\end{tabular}


North Carolina, USA, aboveground Spartina alterniflora production reached mature levels in 3 to $10 \mathrm{yr}$ (Seneca et al. 1976, Broome et al. 1986), while organic carbon reservoirs may take an estimated 4 to $25 \mathrm{yr}$ to develop (Seneca et al. 1976). In naturally developing marshes the sediment grain size generally decreases over time (Redfield 1972, Barnes et al. 1976, Osgood \& Zieman 1993a,b, Walsh 1998). However, initial conditions, such as substrate type and geomorphology, are important in dictating the developmental trends. Simenstad \& Thom (1996) in a Washington, USA, marsh and Cammen $(1976 a, b)$ in a North Carolina marsh found that the shift in grain size depends on the initial grain size of the dredge spoil on which the artificial marsh is established. Lindau \& Hossner (1981), in an artificially created marsh in Texas, USA, found that the rates of nitrogen and organic matter increase varied depending on the relative height within the intertidal zone. Thus, we expect the trajectories of creekbank development to vary depending on the parameters studied and the locally important governing conditions.

A salt marsh chronosequence on Hog Island, Virginia, USA, where marshes ranging from 1 to $150+\mathrm{yr}$ exist side by side, was selected for this study. This site provides a natural experiment where instantaneous observations of successional changes can be made

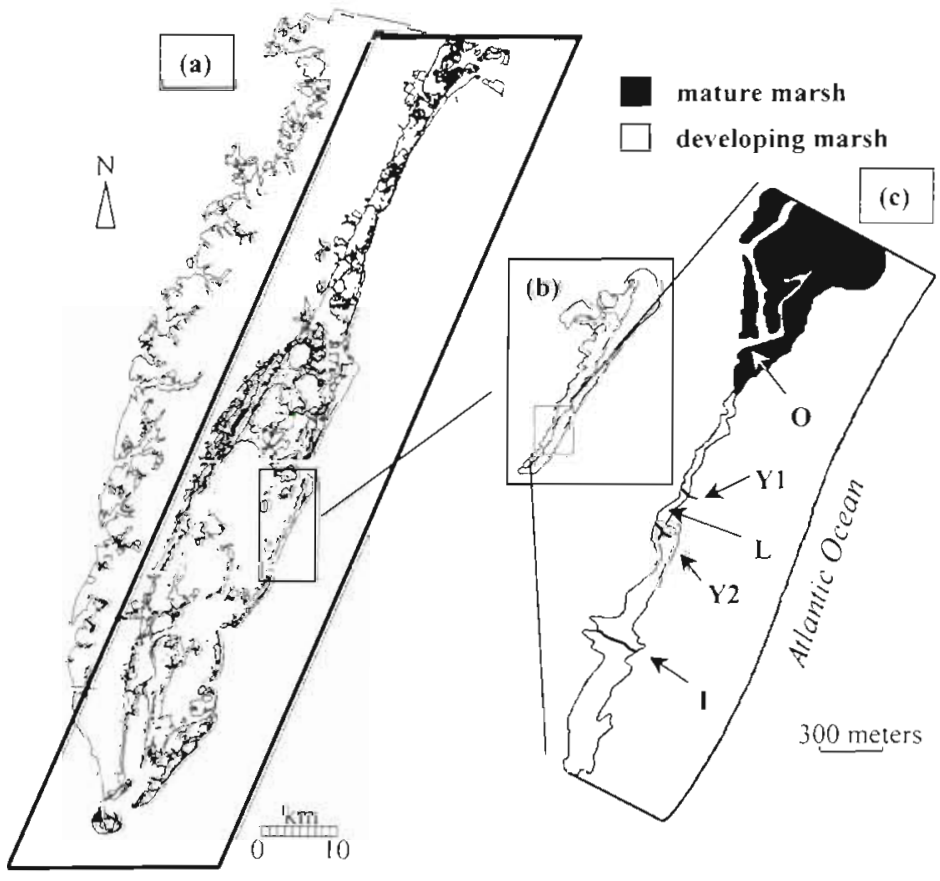

Fig. 1. (a) The southern tip of the Delmarva Peninsula, USA, with the Virginia Coast Reserve designated by the heavy line, (b) Hog Island, and (c) the study area showing each of the sites. Y1 and Y2: young creekbank sites, I: intermediate aged site, O: mature site and L: young lagoon edge site. Shading: extent of the Spartina alterniflora marsh in 1995 through a 'space-for-time' substitution (Pickett 1991). In instituting this 'space-for-time' substitution, we must assume that the 'snap-shots' of ecosystem pattern and process at difference ages represent real trends, and that all of the marshes in this chronosequence are following the same developmental trajectory. Walsh (1998) has described the development of the interior of these marshes based on the Spartina alterniflora height zones. The current study uses a similar approach to describe the rate of development of the marsh at the creekbank, and attempts to determine how creeks influence the developmental trajectory. We examine physico-chemical and biological attributes of the creekbank and the physico-chemistry of creek water over a tidal cycle in the different aged marshes. We hypothesize that the aging process will be accelerated in the creekbank region due to the unique physico-chemistry associated with proximity to the creekbank and an enhancement of the biotic-abiotic feedbacks between the primary producers and their environment.

\section{METHODS}

Site description. This study takes place on Hog Island (Fig. 1a,b), a barrier island off of the coast of the Delmarva Peninsula, Virginia. The island, which is part of the Virginia Coast Reserve Long Term Ecological Research (LTER) project, is a highly dynamic environment subject to frequent disturbances (Hayden et al. 1991). For example, Broadwater, a town with nearly 250 inhabitants at the turn of the century is now underwater some distance east of the current shoreline (Badger \& Kellam 1989). In March 1962 a large and powerful coastal storm caused an overwash event which deposited up to $1 \mathrm{~m}$ of sand over the back-barrier marshes on the southern end of the island (Stewart 1962) and extended the island $-1.5 \mathrm{~km}$ to the South (Fitch 1991). The northern extent of the overwash is just south of Broadwater Creek, and a patch of marsh at the edge of the creek was left undisturbed (Fig. 1C). We have used this site $(O$ in Fig. 1c) as our 'reference' or 'mature' marsh. The age of this marsh is not known precisely, but it is present on maps dating back to 1853 and so is at least 150 yr old. We presume that the marsh platform was laid down by an earlier overwash event. The tidal range in Hog Island Bay is $1.3 \mathrm{~m}$.

Since the 1962 storm, the fringing marshes have gradually regrown on the overwash fan. By inspection of aerial photographs, we have 
determined the time at which Spartina alterniflora recolonized the new sediment platform. For the purposes of this study, we are defining 'marsh age' as the amount of time that has passed since $S$. alterniflora was visible on these photographs; it is therefore the 'ecological' age of the marsh. We selected 2 young creekbank sites (Y1, Y2), an intermediate aged creekbank site (I), and 1 site at the edge of the lagoon ( $L_{i}$ Fig. $1 \mathrm{C}$ ). All of the young marsh sites are underlain by the mature marsh that was buried in the 1962 storm. In 1996 the approximate ages of Sites L, Y1, Y2 and 1 were 2, 5, 6 and $15 \mathrm{yr}$, respectively. All of the creeks run approximately perpendicular to the shoreline and the 3 younger creeks, Y1, Y2, and I, lack the meanders characteristic of mature marshes. $\mathrm{Y} 1$ and $\mathrm{Y} 2$ are each 0.5 to $0.75 \mathrm{~m}$ across and 20 to $30 \mathrm{~m}$ in length. In these creeks, the water becomes discontinuous with the lagoon on the ebb tide once the water has fallen below the level of the mudflat. Y1 drains a catchment area with an ephemeral, brackish pond, while Y2 drains an unvegetated salt flat. I is 1 to $1.5 \mathrm{~m}$ across, is $50 \mathrm{~m}$ long, and becomes discontinuous with the lagoon on the majority of tides. The old creek $(\mathrm{O})$ is 5 to $8 \mathrm{~m}$ across and branches into tributaries; it remains continuous with the lagoon throughout the tidal cycle.

At each of the creeks, we established two $3 \mathrm{~m}$ transects perpendicular to the creek approximately $10 \mathrm{~m}$ upstream from the confluence with the lagoon. The 2 transects were on opposite sides of the creek at Y1, Y2 and $I$, and on the same side at $O$ because of difficulty crossing the creek. Similar transects were established perpendicular to the shoreline at the lagoon site. Past studies indicate that the influence of creekbank morphology on the subsurface hydrological processes extends approximately 2.5 (Agosta 1985, Harvey et al. 1987, Nuttle 1988, Howes \& Goehringer 1994) to $15 \mathrm{~m}$ (Nuttle 1988, Nuttle \& Hemond 1988) from the creekbank. Four sites were established along each transect at $0.5,1,2$ and $3 \mathrm{~m}$, yielding 8 sites in each of the 5 marshes. The elevation relative to mean sea level (MSL) of each site was determined using Pentax Total Station survey equipment. The survey was tied into 5 benchmarks that are part of the LTER benchmark system. These were established using Trimble Survey Grade GPS receivers and are tied to USGS benchmarks on the mainland. The reference datum is the USGS 1967 reduction level. The overall accuracy of the survey is within 0.03 to $0.04 \mathrm{~m}$ of the 1967 USGS reduction level and the within-survey accuracy is $\pm 0.015 \mathrm{~m}$ in the $z$-direction.

Creekbank study. Sediment characteristics: The surface sediment nitrogen content $(\% \mathrm{~N})$ was determined in April, June, August and October of 1995 and 1996. Three replicate, $1 \mathrm{~cm}$ diameter $\times 1 \mathrm{~cm}$ deep cores were taken from each site using a $5 \mathrm{~cm}^{3}$ syringe corer and combined into a single sample. The samples were lyophilized and ground to homogeneity using a mortar and pestle. Prior to grinding, visible shell fragments, large roots and rhizomes were removed. Nitrogen content was determined using a Carlo Erba NA1500 Elemental Analyzer. Samples for grain size and organic content analysis were collected in September 1995. Three replicate, $2.5 \mathrm{~cm}$ diameter $\times 10 \mathrm{~cm}$ deep cores were taken from each site and combined. The fractions of sand, silt and clay were determined using the method of Brower \& Zar (1984). The organic content was determined gravimetrically by loss on combustion at $450^{\circ} \mathrm{C}$.

Porewater chemistry: A suction lysimeter (Chambers \& Odum 1990) was installed to a depth of $10 \mathrm{~cm}$ at each site. Porewater was collected from the lysimeters monthly from June to October 1995 and April to October 1996. All samples were collected on a rising tide. Porewater was extracted from the sipper under anoxic conditions using a syringe. Redox potential and $\mathrm{pH}$ were determined immediately following collection by injecting the sample into an anoxic chamber fitted with Corning electrodes and a temperature probe attached to a Beckman $\$ 12 \mathrm{pH}$ /ISE meter. Salinity was measured using a temperature compensating hand-held refractometer. Samples for $\mathrm{NH}_{4}{ }^{+}$and $\mathrm{PO}_{4}{ }^{3-}$ analysis were immediately filtered through $0.45 \mu \mathrm{m}$ membrane filters into vacutainer tubes containing $6 \mathrm{~N} \mathrm{HCl}$, added to prevent the volatilization of $\mathrm{NH}_{4}{ }^{+}$, and kept on ice. The samples were brought back to the field laboratory and analyzed within $6 \mathrm{~h}$. Each sample was bubbled with $\mathrm{N}_{2}$ gas in order to drive off the $\mathrm{H}_{2} \mathrm{~S}$. Immediately prior to addition of the color reagents, the $\mathrm{pH}$ was readjusted with $6 \mathrm{~N} \mathrm{NaOH}$. Both $\mathrm{NH}_{4}{ }^{+}$and $\mathrm{PO}_{4}{ }^{3-}$ were determined spectrophotometrically as described in Grasshoff et al. (1983). Nitrate + nitrite (hereafter referred to as nitrate) was analyzed using the method of Jones (1984). Nitrate was consistently less than $2 \mu_{\mathrm{mol} \mathrm{l}}^{-1}$ in 1995 and was not measured in 1996. Sulfide concentration was determined using a method described by Cline (1969) as modified by Otte \& Morris (1994).

Spartina alterniflora biomass and tissue element composition: End-of-season S. alterniflora biomass was determined in September 1995 and 1996. At each site three $0.0625 \mathrm{~m}^{2}$ quadrats were thrown randomly and all of the aboveground S. alterniflora was clipped. Each stem was cleaned of sediment and all dead leaves removed. Each stem was measured to the tallest point (leaf or flower), oven dried and weighed. Leaf samples were collected from each site in June, August and October 1995 and 1996 for tissue \%N. Ten to fifteen leaves from different plants were collected and combined into a single sample from each site. The leaves were washed free of sediment and frozen. The samples 
were lyophilized and ground to homogeneity using an electric coffee mill. The \% $\mathrm{N}$ of the tissue was analyzed using a Carlo-Erba NA1500 Elemental Analyzer.

Data analysis: Between-marsh comparisons were made using the SPSS General Linear Model-General Factorial function. When significant differences were found between marshes at $\mathrm{p}<0.05$, post-hoc tests were run. When variances were equal, Tukey's HSD was used; when variances were unequal, the Games-Howell test was used. A principal components analysis (PCA) was run on the variables shown in Table 3 using SPSS. Biomass was not included in the PCA because it was calculated from other variables used. Elevation was also excluded. Between- and within-marsh comparisons were made on the factor scores generated by the PCA using SPSS and post-hoc tests run as described above.

Tidal cycle study. Creek water was sampled on 2 spring tides (14 July and 23 August, 1995) and 2 neap tides (16 September and 15 October, 1995). Samples were collected from each creek and the flooding lagoon at hourly intervals over an entire tidal cycle (12 h) on each date. Salinity and $\mathrm{pH}$ were measured in the field as described above. Particulate carbon and nitrogen were measured by filtering water through pre-combusted $13 \mathrm{~mm}$ glass-fiber filters. The filters were inserted into tin capsules, dried at $60^{\circ} \mathrm{C}$, and analyzed using a Carlo-Erba NA1500 Elemental Analyzer. Particulate matter was determined by filtering creek water through pre-weighed, pre-combusted $47 \mathrm{~mm}$ glass-fiber filters. The filters were dried at $60^{\circ} \mathrm{C}$ and weighed. The organic content of the particulates was determined gravimetrically by loss on combustion at $450^{\circ} \mathrm{C}$. Nutrient samples were filtered as described for the porewater samples and stored on ice. The samples were analyzed for $\mathrm{NH}_{4}{ }^{+}, \mathrm{NO}_{3}{ }^{-}+\mathrm{NO}_{2}{ }^{-}$and $\mathrm{PO}_{4}{ }^{3-}$ as described above. Data from the 4 tidal cycles were pooled, and averages were made at hourly intervals based on the time since high tide.

\section{RESULTS}

The lagoon site was scoured considerably during the winter of 1995-1996. Destruction of the belowground Spartina alterniflora biomass was evident in the early spring of 1996, and there appeared to be elevational changes. After the winter scouring the mature marsh that was buried in 1962 was much closer to the surface of the new marsh. Old marsh material probably sup-

Table 2. Overall mean salt marsh characteristics for each site. Numbers in parentheses are the standard error of the mean. Values with the same letter are not significantly different from each other $(p<0.05)$. Sampling frequency: geomorphology-once; porewater characteristics - monthly; sediment characteristics-once, except \% $\mathrm{N}$, which was sampled bimonthly; salt marsh cord grass characteristcs - yearly, except $\% \mathrm{~N}$ and $\mathrm{C}: \mathrm{N}$, which were sampled bimonthly

\begin{tabular}{|c|c|c|c|c|}
\hline & Y1 & $\mathrm{Y} 2$ & I & $\mathrm{O}$ \\
\hline \multicolumn{5}{|l|}{ Geomorphology } \\
\hline Elevation ( $\mathrm{m}$ rel. to MSL) & $0.56(0.01)^{d}$ & $0.52(0.01)^{\mathrm{a}}$ & $0.09(0.02)^{b}$ & $-0.20(0.02)^{\mathrm{c}}$ \\
\hline Creekbank slope $\left(\times 10^{-2}\right)$ & $4.9(0.6)^{\mathrm{d}}$ & $4.9(0.7)^{\mathrm{a}}$ & $4.5(3.4)^{\mathrm{a}}$ & $8.7(1.1)^{\mathrm{a}}$ \\
\hline \multicolumn{5}{|l|}{ Porewater } \\
\hline Salinity (ppt) & $26.8(0.8)^{\mathrm{d}}$ & $36.6(0.4)^{\mathrm{b}}$ & $33.5(0.3)^{\mathrm{c}}$ & $33.7(0.2)^{\mathrm{c}}$ \\
\hline $\mathrm{Eh}(\mathrm{mV})$ & $106.9(7.2)^{\mathrm{d}}$ & $113.8(6.3)^{a}$ & $-0.4(9.7)^{\mathrm{b}}$ & $-5.0(11.8)^{\mathrm{b}}$ \\
\hline $\mathrm{pH}$ & $6.9(0.03)^{d}$ & $6.6(0.04)^{\mathrm{b}}$ & $6.9(0.04)^{a}$ & $6.9(0.03)^{a}$ \\
\hline$S^{2-}\left(\mu \mathrm{mol} l^{-1}\right)$ & $22.8(6.0)^{\mathrm{d}}$ & $9.5(2.9)^{d}$ & $240.2(34.2)^{\mathrm{b}}$ & $432.5(82.1)^{\mathrm{c}}$ \\
\hline $\mathrm{PO}_{4}^{3-}\left(\mu \mathrm{mol} \mathrm{l} l^{-1}\right)$ & $15.9(1.6)^{\mathrm{a}}$ & $2.9(0.3)^{b}$ & $36.4(2.9)^{c}$ & $42.4(3.4)^{c}$ \\
\hline $\mathrm{NH}_{4}^{+}\left(\mu \mathrm{mol} \mathrm{I} I^{-1}\right)$ & $11.1(2.1)^{\mathrm{a}}$ & $9.5(1.1)^{\mathrm{a}}$ & $21.8(2.2)^{\mathrm{a}}$ & $59.1(6.4)^{\mathrm{b}}$ \\
\hline \multicolumn{5}{|l|}{ Sediment } \\
\hline$\% N$ & $0.02(0.01)^{a}$ & $0.02(0.01)^{\mathrm{a}}$ & $0.06(0.01)^{\mathrm{b}}$ & $0.18(0.01)^{c}$ \\
\hline$\%$ organic matter & $0.7(0.1)^{a}$ & $0.7(0.1)^{\mathrm{a}}$ & $1.2(0.1)^{\mathrm{b}}$ & $4.5(0.2)^{c}$ \\
\hline$\%$ clay & $9.5(0.6)^{a}$ & $10.2(0.8)^{d}$ & $15.2(0.8)^{\mathrm{b}}$ & $26.8(0.8)^{\mathrm{c}}$ \\
\hline$\%$ sand & $88.0(0.8)^{\alpha}$ & $86.5(1.0)^{\mathrm{a}}$ & $77.6(0.8)^{\mathrm{b}}$ & $13.3(1.3)^{\mathrm{c}}$ \\
\hline$\%$ silt & $2.3(0.4)^{\mathrm{a}}$ & $3.3(0.4)^{\circ}$ & $7.0(0.4)^{\mathrm{b}}$ & $60.1(0.7)^{\mathrm{c}}$ \\
\hline \multicolumn{5}{|l|}{ Spartina alterniflora } \\
\hline$\% \mathrm{~N}$ & $1.21(0.08)^{a}$ & $1.28(0.03)^{\mathrm{a}}$ & $1.52(0.05)^{b}$ & $2.06(0.08)^{c}$ \\
\hline$C: N$ & $44.80(1.75)^{\mathrm{a}}$ & $39.36(1.06)^{\circ}$ & $33.34(1.08)^{b}$ & $24.63(1.00)^{\mathrm{c}}$ \\
\hline Biomass $\left(\mathrm{g} \mathrm{m}^{-2}\right)$ & $805.8(143.7)^{\circ}$ & $270.4(39.1)^{b}$ & $956.8(61.0)^{d}$ & $976.9(49.6)^{\mathrm{a}}$ \\
\hline Density (stems $\mathrm{m}^{-2}$ ) & $401(22)^{\mathrm{d}}$ & $380(28)^{a}$ & $561(50)^{b}$ & $440(31)^{d}$ \\
\hline$\%$ flowering & $15(1)$ & $13(2)^{\mathrm{d}}$ & $24(2)^{\mathrm{b}}$ & $35(3)^{c}$ \\
\hline Weight (g stem ${ }^{-1}$ ) & $1.8(0.2)^{\mathrm{a}}$ & $0.7(0.1)^{b}$ & $1.9(0.2)^{\mathrm{d}}$ & $2.4(0.2)^{a}$ \\
\hline Height (cm stem $\left.{ }^{-1}\right)$ & $40.9(2.7)^{\mathrm{d}}$ & $27.6(1.3)^{\mathrm{b}}$ & $44.1(2.2)^{\mathrm{d}}$ & $55.7(2.5)^{\mathrm{c}}$ \\
\hline
\end{tabular}


Fig. 2. Sediment percent sand, percent silt, percent clay, organic content, percent total nitrogen, and porewater salinity, redox potential, and sulfide, phosphate, and ammonium concentrations at the salt marsh sites. Error bars represent the standard error of the mean. See Fig. 1 legend for site abbreviations sediment properties
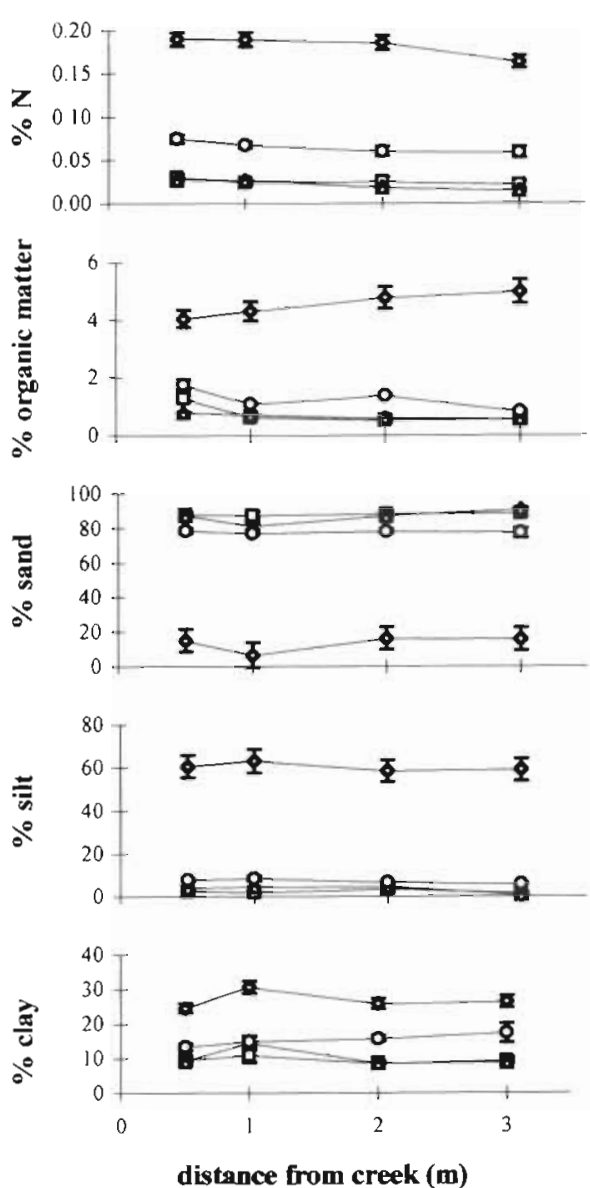

pore water chemistry
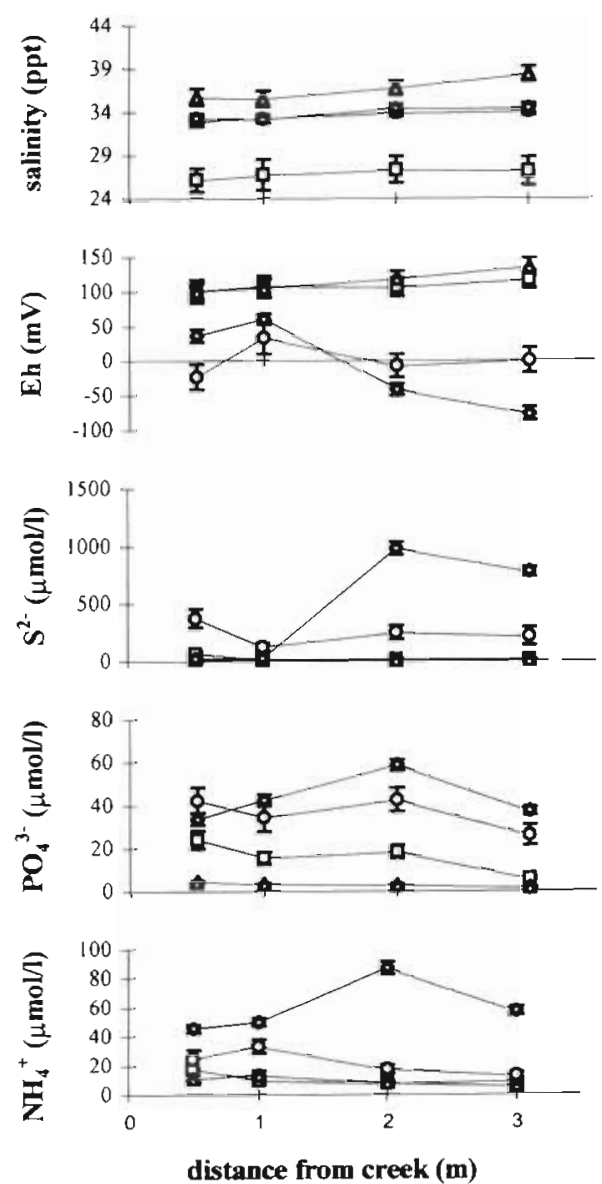

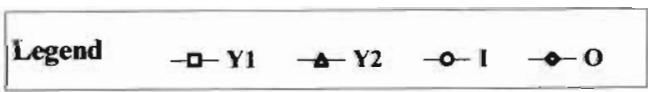

plied high concentrations of $\mathrm{PO}_{4}{ }^{3-}$ to the porewater. In addition, at the sites $0.5 \mathrm{~m}$ from the edge of the lagoon, the redox potential was very low, most likely due to the high organic content of the buried marsh. For these reasons, this site was not included in the majority of the data analyses presented here. It was, however, used in the PCA for comparison between marshes developing with and without creeks.

\section{Geomorphology}

The sediment elevation relative to MSL and the creekbank slopes are listed in Table 2 . The 2 youngest creeks were approximately $0.5 \mathrm{~m}$ above MSL, I was at MSL, and $O$ was $0.20 \mathrm{~m}$ below MSL. The slopes of the 3 younger marshes are comparable, and are not as steep as the old marsh creekbank. The differences between sites are not significant, probably because the slope was calculated for only 2 transects at each creek- bank. Elevation is significantly correlated with age $\left(\mathrm{r}^{2}\right.$ $=0.83, p<0.001$.

\section{Creekbank study}

Porewater chemistry

With the exception of salinity, the between-year and between-month differences for all variables were slight, so we pooled all temporal replicates. Comparisons were made both between different aged marshes (Table 2) and within each marsh (Fig. 2). Porewater salinity was higher in August and September, most likely due to the increased evapotranspiration resulting from higher temperatures and greater Spartina alterniflora biomass. There was no difference in mean salinity between $I$ and $O$, but there was a significant 10 ppt difference between Y1 and Y2 (Table 2; p < 0.001 ). The mean $\mathrm{pH}$ at $\mathrm{Y} 2$ was 6.6 and at all other sites was approximately 7 . There was no difference in redox 

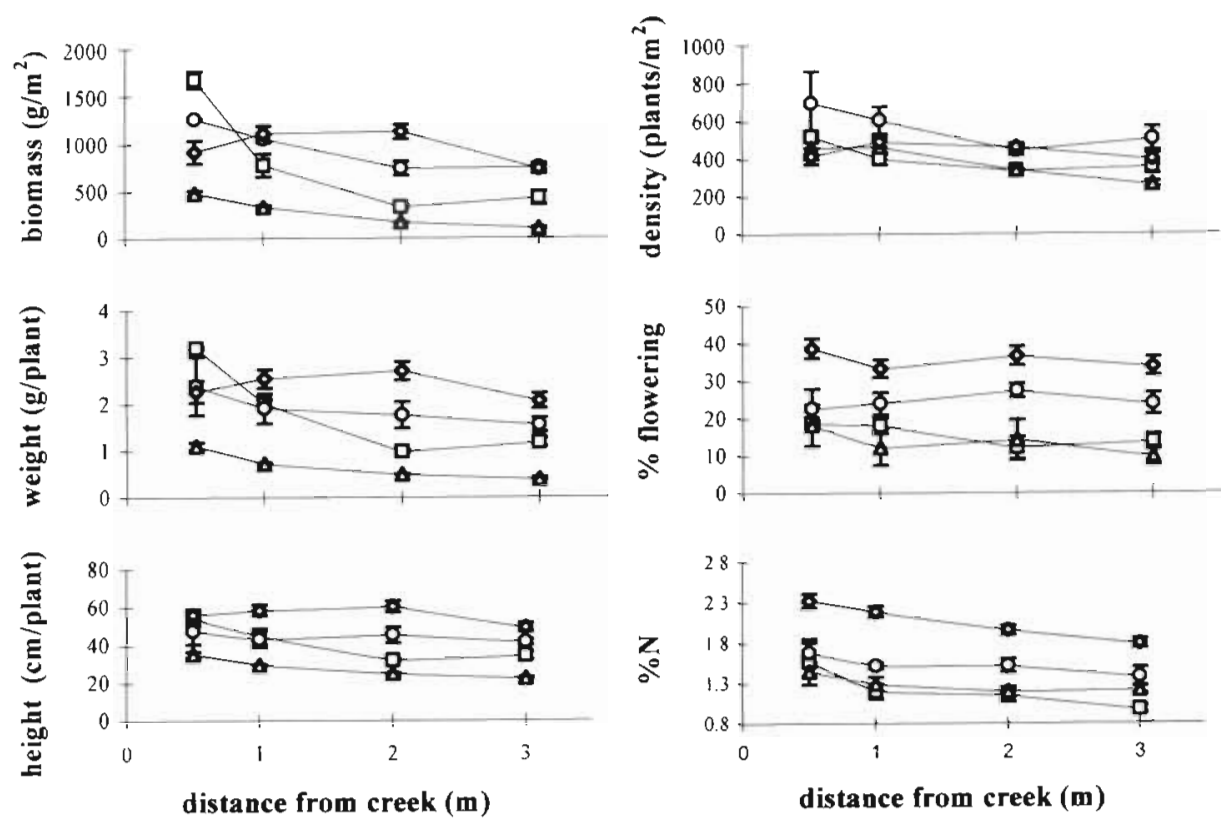

Fig. 3. Spartina alterniflora end of season biomass, stem density, individual stem height, individual stem weight, percentage of plants flowering at the end of the growing season, and tissue nitrogen at the salt marsh sites. Error bars represent the standard error of the mean. See Fig. 1 legend for site abbreviations

potential between $\mathrm{Y} 1$ and $\mathrm{Y} 2$, or between $\mathrm{I}$ and $\mathrm{O}$; however, these 2 groupings were significantly different from each other $(\mathrm{p}<0.05)$. While there was an increase in Eh with distance from the creek in the 2 young marshes, the maximum Eh occurred at $1 \mathrm{~m}$ from the creek in the older marshes (Fig. 2). The sulfide concentration in the old marsh was inversely related to the redox potential, and was highest where the redox was lowest further from the creek. Mean $\mathrm{NH}_{4}{ }^{+}$and $\mathrm{PO}_{4}{ }^{3-}$ concentrations (Table 2) increased with marsh age. There was no trend within each marsh for $\mathrm{NH}_{4}{ }^{+}$ (Fig. 2), but in the younger marshes $\mathrm{PO}_{4}{ }^{3-}$ decreased with increasing distance from the creek (Fig. 2). Nitrate was consistently less than $2 \mu \mathrm{M}$ (data not shown).

\section{Sediment characteristics}

For all of the sediment properties measured, there were no significant differences between $Y 1$ and $Y 2$, while I and $O$ are each significantly different from all others $(p<0.05$; Table 2$)$. With increasing age, the sand fraction decreased, while silt, clay, organic matter, and $\mathrm{N}$ content $(\% \mathrm{~N})$ increased. The $\%$ organic matter was positively associated with increasing distance from the creek edge in the old marsh, and negatively associated in the 3 younger marshes (Fig. 2). There is an inverse relationship between $\% \mathrm{~N}$ and distance from the edge for all marshes (Fig, 2).
Spartina alterniflora biomass and tissue composition

The aboveground biomass increased with age, but only Y2 was significantly different from the others $(\mathrm{p}<$ 0.05 ; Table 2). Y2 had significantly lower biomass, plant weight, and plant height when compared to all other marshes. The old marsh had the tallest plants and these plants were more likely to be flowering. In all 3 of the immature marshes, the biomass per $\mathrm{m}^{2}$ and the average weight per stem declined with increasing distance from the creek (Fig. 3). This trend was not observed in the old marsh, where there was no apparent relationship between distance and biomass. Overall, at $0.5 \mathrm{~m}$ from the creekbank, Y1 had the highest biomass $\left(1689.3 \mathrm{~g} \mathrm{~m}^{-2}\right)$, and the highest weight per stem ( $\left.3.2 \mathrm{~g} \mathrm{plant}^{-1}\right)$, and I had the greatest density $\left(695\right.$ stems $\left.\mathrm{m}^{-2}\right)$. Stem height decreased with distance in $Y 1$ and $Y 2$, but was constant in I and $O$. There was no difference in sexual reproduction (percent of plants flowering) with respect to the distance from the creekbank. The very high biomass $0.5 \mathrm{~m}$ from the creekbank at $Y 1$ causes the grand mean for that marsh to be very high.

Spartina alterniflora tissue $\% \mathrm{~N}$ increased significantly with age $(p<0.05)$. Thus, in the older marsh, there was a greater amount of aboveground nitrogen both per gram of plant tissue, and overall, due to the higher biomass. For all marshes there was a decrease in $\% \mathrm{~N}$ for plants growing farther from the creek. There 
is a significant relationship ( $\mathrm{p}<0.001$ ) between $S$ alterniflora tissue $\mathrm{N}$ and porewater $\mathrm{NH}_{4}{ }^{+}$concentration.

\section{Principal components analysis}

The principal components analysis resulted in 4 significant principal component vectors. The first 2 principal components, PC1 and PC2, explained 53.4 and $12.5 \%$ of the variability in the data set. The factor loadings associated with each variable for PC1 and PC2 are shown in Table 3. PC1 is positively associated with organic content, sediment $\mathrm{N}$, silt and clay, porewater $\mathrm{NH}_{4}{ }^{+}, \mathrm{PO}_{4}{ }^{3-}$ and $\mathrm{S}^{2-}$, Spartina alterniflora stem height, weight $\%$ flowering and $\% \mathrm{~N}$, and negatively associated with sand and redox potential, as shown in Fig. 4c. There is a significant relationship between the factor scores for PC1 and both age and elevation $(\mathrm{p}<0.001)$. The mean factor scores are $-0.52,-0.54,-0.89,0.15$, and 1.79 for $L, Y 1, Y 2, I$ and $O$, respectively (Fig. 4a). These values are all significantly different from each other for all of the creek sites $(p<0.001)$; $L$ is significantly different $(p<0.001)$ from all sites but Y1. Fig. $4 b$ shows the relationship between mean factor score for PC1 for each site and distance from the creek. For the lagoon site and the old marsh, there is no pattern in factor scores with increasing distance. In the immature marshes there are significant differences between distances $(p<0.05)$. In all cases, the factor score, which we will use as a proxy for the ecological or successional
Table 3. Variables used in the principal components analysis and the factor loadings associated with each variable for principle component 1 (PC1) and principle component 2 (PC2). Factor loadings in italics show a strong (loading $>0.5$ ) relationship with the principal component

\begin{tabular}{|c|c|c|}
\hline \multirow[t]{2}{*}{ Variable } & \multicolumn{2}{|c|}{ Factor loading } \\
\hline & PC1 & $\mathrm{PC} 2$ \\
\hline \multicolumn{3}{|c|}{ Pore water chemistry } \\
\hline $\mathrm{NH}_{4}{ }^{+}$ & 0.84 & 0.03 \\
\hline Eh & -0.64 & 0.34 \\
\hline $\mathrm{PO}_{4}^{3-}$ & 0.55 & -0.18 \\
\hline $\mathrm{S}^{2-}$ & 0.53 & -0.12 \\
\hline $\mathrm{pH}$ & 0.40 & -0.67 \\
\hline Salinity & 0.01 & 0.83 \\
\hline \multicolumn{3}{|c|}{ Sediment characteristics } \\
\hline$\% \mathrm{~N}$ & 0.94 & 0.11 \\
\hline$\%$ organic matter & 0.93 & 0.11 \\
\hline$\%$ sand & -0.93 & -0.16 \\
\hline$\%$ silt & 0.92 & 0.18 \\
\hline$\%$ clay & 0.90 & 0.09 \\
\hline \multicolumn{3}{|c|}{ Spartina alterniflora } \\
\hline Stem height & 0.82 & -0.19 \\
\hline$\%$ flowering & 0.74 & 0.27 \\
\hline$\% \mathrm{~N}$ & 0.81 & 0.26 \\
\hline Stem weight & 0.71 & -0.18 \\
\hline Density & 0.15 & -0.63 \\
\hline
\end{tabular}

maturity of the site, increases as one approaches the creek. It follows, therefore, that the marsh more closely resembles a mature marsh closer to the creekbank than further from the creekbank. For example, the mean factor score $0.5 \mathrm{~m}$ from the creekbank at $\mathrm{Y} 1$ is

(b)

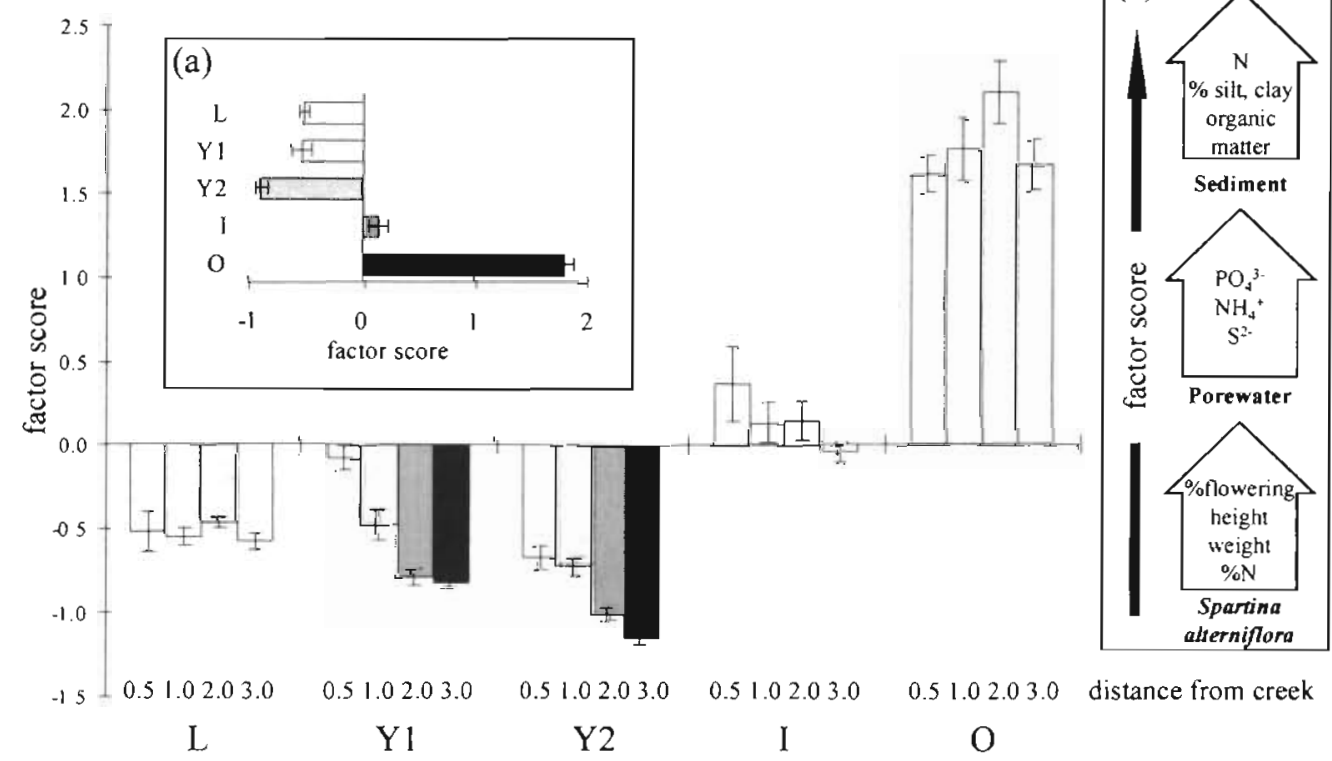

Fig. 4. Factor scores from PC1 in the principal components analysis. (a) Overall mean factor score for each marsh site. (b) Means for each site. (c) Trends associated with a positive increase in factor score. All site abbreviations as in Fig. 1 legend, except: L, lagoon site. Bars with similar shading are not significantly different $(\mathrm{p}<0.05)$. Error bars are the standard error of the mean 

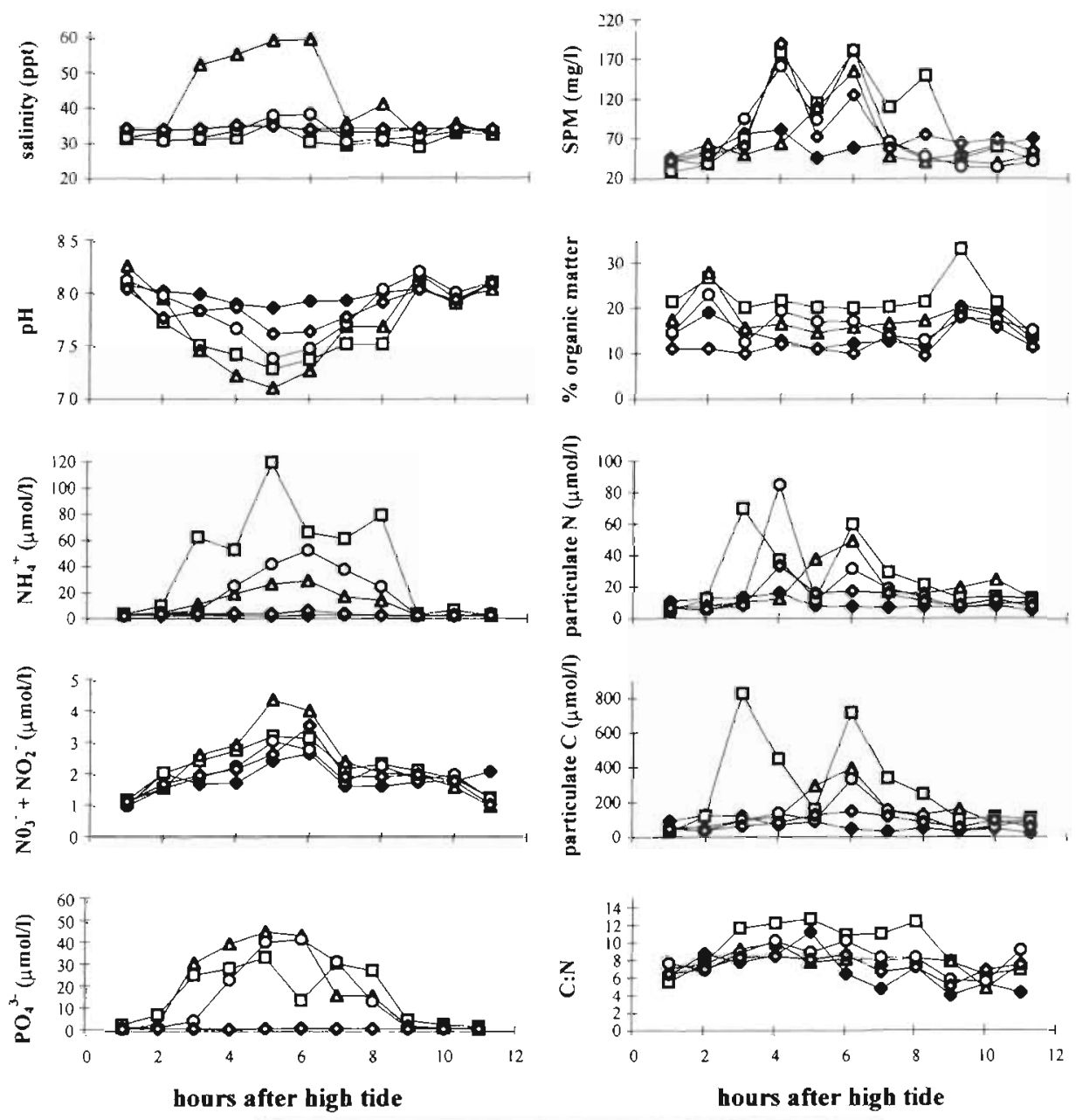

Fig. 5. Mean hourly values for salinity, $\mathrm{pH}, \mathrm{NH}_{4}^{+}, \mathrm{NO}_{3}^{-}+\mathrm{NO}_{2}^{-}$. $\mathrm{PO}_{4}{ }^{3-}$, suspended particulate matter (SPM), organic content of particulate matter, particulate $N$, particulate $C$, and $C: N$ of particulate matter for each creek over a tidal cycle. Values are averages of samples taken in July, August, September and October of 1995

the same as the mean factor score $3 \mathrm{~m}$ from the creekbank at $I$, indicating that these 2 sites have a similar functional maturity.

PC2 is associated with low Spartina alterniflora stem density, low $\mathrm{pH}$ and high salinity. The factor scores for PC2 are not correlated with elevation or age $(p>0.9)$ and this set of variables describes a different trajectory. The conditions described by this vector are met at $Y 2$, where the PC2 factor scores are significantly different $(p<0.001)$ from all other young marshes, including $L$.

\section{Tidal cycle study}

Owing to the variability in some of the creek water measurements, statistical analysis of the trends was not possible. However, there were some distinct and relevant patterns observed. The $\mathrm{pH}$ of the lagoon showed a slight depression around low tide, and all of the creeks had a large depression in $\mathrm{pH}$ during low tide (Fig. 5). At high tide all creeks had the same $\mathrm{pH}$ as the flooding water $(\sim 8)$. In all but $Y 2$, the salinity remained fairly close to the salinity of the lagoon (33 ppt $\mathrm{t}_{i}$ Fig. 5). Y2 had salinities of 50 to $60 \mathrm{ppt}$ at low tide, suggesting that salty water is being discharged into the creek from the adjacent salt flat. While the nutrient concentrations in the lagoon and the old creek remained relatively constant over the tidal cycle, the 3 developing marshes showed a marked increase in $\mathrm{NH}_{4}{ }^{+}$and $\mathrm{PO}_{4}{ }^{3-}$ concentrations during the falling tide and a subsequent dilution as the creeks flooded. Nitrate increased in all creeks and in the lagoon during low tide (Fig. 5).

The concentration of particulates remained low in the lagoon over the tidal cycle (Fig. 5). Despite some inconsistent measurements, the average concentration of particulates and the percentages of organic matter, $\mathrm{N}$ and $\mathrm{C}$ in the particulates increased as the tide ebbed in the younger creeks. At all sites, but especially Y1, the $\mathrm{C}: \mathrm{N}$ of the particulate matter was higher as the tide 
was falling. This could be explained by plant material being flushed from the marsh surface into the creek as the tide went out. The SPM concentration was highest at low tide in all of the creeks.

\section{DISCUSSION}

Hydrogeomorphology is generally thought to be the primary factor controlling salt marsh function. A confounding factor in this study, and for the future usefulness of the Hog Island marsh chronosequence, is the fact that the different aged marshes vary so greatly in elevation. The statistical relationship between elevation and ecological age is significant $(p<0.001)$, and the old marsh is substantially lower than the younger marshes. This is to be expected given that the sediment platform for the younger marshes was deposited on top of a mature marsh that was, at one time, contiguous with our mature, reference marsh. We therefore need to determine whether the observed variation across the chronosequence is due solely to elevation or if age is also an important factor. However, the correlation between age and elevation precludes a direct comparison of age and elevation effects, so it may prove difficult to determine the relative influence of these factors.

An idea that is fundamental to understanding marsh development is the relationship between elevation and the timing of vascular plant establishment. In a summary of work on developing marshes in England, Gray (1992) states that elevation is the primary determinant of niche boundaries between Spartina anglica and high marsh plants. Bertness (1991) demonstrated that the lower intertidal limit for $S$. patens is set by its tolerance to waterlogging. The lower elevation at the creekbank creates more waterlogged, anoxic conditions that exclude $S$. patens and permit the establishment of $S$. alterniflora. The lower intertidal limits for $S$, alterniflora are also set by the inundation time (Mitsch \& Gosselink 1993). The 3 young creek/marsh systems in this study are narrow bands ( 15 to $50 \mathrm{~m}$ ) of $S$. alterniflora surrounded by a patchwork of high marsh vegetation (S. patens, Distichlis spicata, Limonium carolinianum and Salicornia spp.) and unvegetated sand flats. Inspection of the time series of aerial photographs indicates that the high marsh develops before the low marsh. It is probable that the formation of creek channels by tidal scouring (i.e. the lowering of the sediment surface) in the high marsh promoted the invasion and subsequent dominance of $S$, alterniflora, as observed by Roozen \& Westhoff (1985).

On the Hog Island overwash we have also observed small drainage channels which form through unvegetated sand flats during storm and extreme high tide events. These channels expand laterally over time and the edges are eventually colonized by Spartina alterniflora. Sandy creekbanks migrate and erode more rapidly than muddy creekbanks due to the lower cohesiveness of sandy sediments (Shi et al. 1995), and vegetation controls the erosion of the creekbanks (Garofalo 1980). Thus, in the early stages of creek development, the sandy substrate and lack of vegetation allows for rapid channel expansion. The size of the creek is thereby related to its age; young creeks are small and in this study are at higher elevations. The lower elevation of the creekbanks relative to the surrounding sediment platform will increase the tidal inundation time, and increase the deposition of finer grained sediments. Erosion of the less cohesive sand fraction and the subsequent change in the relative proportions of silt, clay and sand may cause a continued decrease in marsh elevation by compaction of pore spaces, although in general we expect back-barrier marshes to increase in elevation (Godfrey \& Godfrey 1976). It appears that there is a threshold combination of elevation and slope that is necessary for $S$ alterniflora colonization, such that lower elevations will become vegetated earlier, but that elevation probably doesn't continue to decrease with age. In this fashion, elevation determines when the developmental clock is set. In this study we have examined elevational effects between and within marshes. The between-marsh comparison results from the fact that the different aged marshes are at different elevations, which prevents us from drawing conclusions on developmental processes based solely on marsh age. The within-marsh comparison results from the local slope associated with the creekbank, and can be used to illustrate the effect that creekbank morphology has on the aging process.

\section{General developmental trajectories}

Fig. 6 is a conceptual model illustrating the processes involved in marsh development following the establishment of vegetation. Spartina alterniflora contributes organic matter to the sediment in the form of wrack and dead roots and rhizomes (Fig. 6, arrow 10), which increases organic $\mathrm{C}, \mathrm{N}$ and $\mathrm{P}$ in the substrate. $\mathrm{N}$ fixation, which is fueled by organic $C$ (Langis et al. 1991) and remineralization lead to increased $N$ and $P$ in the porewater (arrow 14). Oxidation of reduced carbon compounds lowers the porewater redox potential, leading to anaerobic degradation pathways and increased porewater $\mathrm{S}^{2-}$ (arrow 15). Waterlogging at low elevations also decreases the redox potential. Low redox potential may eventually have a negative effect on plant growth (arrow 9), but may increase the availability of reactive $P$. Increases in $\mathrm{N}$ and $\mathrm{P}$ promote 
additional S. alterniflora growth and tissue $\mathrm{N}$ (arrow 7) which completes the positive feedback loop described by arrows 10,14 and 7 . Over time fine grained sediments are deposited on the marsh, and the rate of deposition is determined by a combination of elevation (arrow 3, Pethick 1992) and plant density (arrow 11, Stumpf 1983). The change in the relative proportions of grain size fractions decreases the hydraulic conductivity, $K$ (arrow 12, Freeze \& Cherry 1979). Lower $K$ decreases nutrient flushing and loss during ebb tide (arrows 13 and 4) and decreases the redox potential by limiting the sediment aeration (arrow 6). The above feedback processes are controlled to varying extents by marsh age, surface elevation and slope. The effects of the slope will be discussed in relation to the devel- opment of the marsh along the creekbank. The overall surface elevation influences the establishment of the marsh and thereby its age, and also influences such processes as sediment deposition, sediment aeration, redox potential and decomposition. The age of the marsh is integral in determining the magnitude of many of the parameters described above. For example, it takes time to accumulate the large organic matter reservoirs found in mature marshes. Thus, a parameter such as organic matter is controlled by a combination of age and elevation and we cannot realistically separate out the relative contributions of each. For this reason, we can only discuss our observed trends along this chronosequence as they relate to the combined factor of age and elevation.

There are clearly general patterns associated with increasing age and decreasing elevation in the marshes on Hog Island. These trends are described by PC1, as illustrated in Fig. 4. There is an increase in sediment organic content, $\% \mathrm{~N}$, and fine grained particles. The porewater has higher nutrient concentrations and lower redox status. These trends are consistent with the trends reported in the literature, as outlined in Table 1 for young versus old marshes. In general, mature marshes at higher elevations have higher organic content than lower elevation marshes (Mitsch \& Gosselink 1993). This implies that the difference we have observed in the chronosequence marshes on Hog Island can be attributed to age.

Spartina alterniflora biomass is not clearly associated with either age or elevation in this system, probably due to the myriad of factors (e.g. salinity, redox potential, $N$ availability) that control $S$. alterniflora production and the variability in these factors across the chronosequence. Despite the variability in biomass, there is a clear trend of increasing tissue $\% \mathrm{~N}$ across the sites. The increased $\% \mathrm{~N}$ with age is consistent with the results of Langis et al. (1991) in a comparison of restored and natural marshes in Southern California, USA, but contrasts with the results of Osgood \& Zieman (1993a) in other different aged back-barrier marshes within the Virginia Coast Reserve. The porewater $\mathrm{NH}_{4}{ }^{+}$concentration in Osgood and Zieman's young
Fig. 6. Schematic diagram illustrating biotic-abiotic interactions in the creekbank zone of a salt marsh. * indicates that an increase in the donor box causes an increase in the recipient box. Indicates that an increase in the donor box causes a decrease in the recipient box. The numbers are referred to in the text. $K$ : hydraulic conductivity; ET: evapotranspiration 
marsh was higher $(39.4 \pm 8.3 \mu \mathrm{M})$ than in either this study (range: $9.5 \pm 1.1 \mu \mathrm{M}$ at $\mathrm{Y} 2$ to $21.8 \pm 2.2 \mu \mathrm{M}$ at $\mathrm{I}$ ) or that of Langis et al. (range: $7.9 \pm 0.7 \mu \mathrm{M}$ to $20.0 \pm 5 \mu \mathrm{M}$ ). Osgood \& Zieman attributed the lower tissue $N$ of old marsh plants to inhibition of $N$ uptake at low redox potential (Osgood \& Zieman 1993a). Given the low porewater $N$ in the young marshes in this study, we suggest that the low tissue $\mathrm{N}$ in the younger marshes is due to direct $N$ limitation. Plants in the old marsh are also more likely to reproduce sexually relative to plants in a young marsh, and have greater stem height and weight. The physiological and structural variation present in this species over the chronosequence is evidence that even though the biomass does not change predictably, some aspects of the physiology and reproduction show distinct developmental trends

\section{Developmental trajectories at the creekbank}

In the young marshes the region closest to the creekbank appears to be more functionally mature because it has a higher mean factor score for PC1 relative to regions farther from the creek edge (Fig. 4). In the lagoon marsh, there is no trend in the factor scores with relation to the edge, suggesting that the creek is important in determining the spatial patterns of functional maturity found at the creek edge. Many of the variables associated with $\mathrm{PC} 1$, and hence with marsh maturity, show similar trends when contrasted with distance from the creek. In a sense, a mini-chronosequence is formed at the edge of the creek.

The Spartina alterniflora biomass is highest closest to the creekbank in the younger marshes, even though the porewater nutrient concentration is low. Osgood \& Zieman (1998) postulated that in young marshes the hydraulic gradient established by the creekbank slope and relatively high $K$ results in a greater flux of nutrients through the root zone, which augments the rate of nutrient supply to the plants (Fig. 6, arrows 2 and 4). This may explain the higher tissue $\mathrm{N}$ content in plants growing closer to the creek. Higher flushing rates also control the build-up of salts and toxins (arrows 5 and 6 ) that may otherwise limit growth (arrows 8 and 9). Higher biomass at the creekbank probably results in greater organic matter contribution and sediment accumulation (arrows 10 and 11), in accord with Lindau \& Hossner (1981), who found that organic content and total $\mathrm{N}$ were higher lower in the intertidal zone in a young, transplanted marsh. Owing to the importance of local geomorphology, the magnitude of the feedback processes associated with marsh development varies spatially, even within a single marsh. These feedback processes can lead to an acceleration of the rate of development, such that development occurs more rapidly closest to the creekbank. In addition, there are processes within the creek that act to accelerate the maturation of the marsh in the immediate vicinity of the creek.

Mature salt marshes exhibit tightly coupled, recycling based nutrient cycles (Aziz \& Nedwell 1986. Anderson et al. 1997) in comparison to young marshes (Thompson et al. 1995). According to general theories of ecosystem development, young ecosystems tend to import nutrients and are inherently leaky due to poorly developed nutrient cycles in comparison to mature systems (Odum 1969, Vitousek \& Reiners 1975). The exchange of nutrients between marshes and estuaries has been intensively studied (e.g. Wolaver \& Spurrier 1988, Wolaver et al. 1988, Craft et al. 1989, Dame et al. 1992, Childers et al. 1993, Dame \& Gardner 1993, Childers 1994). In immature marshes the fluxes of nutrients are high in comparison to mature marshes (Childers et al. 1993); in young marshes with a tidal range of more than $\sim 1 \mathrm{~m}$, the marshes should take up nutrients and organic matter from the flooding water (Childers 1994). In a study of exchanges in transplanted marshes in North Carolina, Craft et al. (1989) observed export of DOC and DON (dissolved organic carbon and nitrogen) and import of DIN and DIP (dissolved inorganic nitrogen and phosphorus). Tidal creeks are the conduits within which the exchange of materials between the marsh and the surrounding estuary takes place.

In the young creeks on Hog Island we have observed very high concentrations of nutrients and particulates (Fig. 5), indicating a potentially substantial nutrient export. As the tide falls, nutrients and other solutes are leached out of the sediments and into the creeks. Given the higher elevation and hydraulic conductivity of young creek sediments, it is likely that more water and hence more nutrients are lost per unit area of creekbank in younger compared to older marshes (Harvey et al. 1987, Howes \& Goehringer 1994, Osgood unpubl.). These processes correspond to arrows 2 and 4 in Fig. 6. However, because of the high elevation and shallow depth of the young creeks in this study, once the tide is lower than the creek bottom, all dissolved nutrients and particulates leaching from the creekbank or coming from the marsh surface are trapped. This could be true of small creeks in an older marsh as well, but due to the lower overall elevation of the old marshes on Hog Island, this process has not been observed. Given the low tide disconnection between the young creeks and the lagoon, and the extreme variability in the data, it is difficult to quantitatively estimate material fluxes from the marsh. On the rising tide, nutrients and particulates in the creeks mix with the flooding water and are returned to the vegetated portion of the marsh by over-bank flooding 
and infiltration into the subsurface (arrows 1 and 3 , Fig. 6). Small creeks increase the nutrient supply to the plants directly by retaining nutrients within the system and indirectly by increasing the flow past the roots. Reed (1988) showed that creeks retain particulates during 'normal' tides, but particulates are deposited in the marsh during storm events and extreme tides. The grain size of the region closest to the creekbank should attain values characteristic of an older marsh more rapidly than areas further towards the marsh interior.

\section{Rates of development}

For most of the variables that are associated with age, $Y 1$ and $Y 2$ tend to be grouped together. For sediment characteristics such as grain size, organic matter and $N$ content, $I$ is at an intermediate stage between the young marshes and the older marsh. However, for $\mathrm{NH}_{4}{ }^{+}$concentration, I groups with the young marshes, and, for $\mathrm{PO}_{4}{ }^{3-}$ concentration and Eh, I groups with $\mathrm{O}$. In the latter case, the redox status of the sediment may be controlling the $\mathrm{PO}_{4}{ }^{3-}$ availability. It appears that different variables reach their 'mature' levels at different points in the aging process. This is consistent with Walsh (1998), who demonstrated that Spartina alterniflora biomass achieves 'mature' levels before physicochemical parameters or marsh epifaunal density in the interior marshes of the Hog Island chronosequence. This is also consistent with several studies in created marshes, where, for example, development of organic content (Piehler et al. 1998), macrofaunal community structure (Levin et al. 1996), and sediment nutrient reservoirs lag behind vascular plant biomass.

The factor scores from PC1. can be used as a proxy for the maturity of the marsh, and can therefore be used to gauge the rate of development at each site. Using these factor scores, the sequence of functional maturity of these marshes is: Y2, L, Y1, I and O, from youngest to oldest (Fig. 4). Thus, Y1 appears to be developing faster than $Y 2$. The rate at which development proceeds varies spatially within the marsh, with the highest rates closest to the creekbank. There is a positive feedback between the geomorphology associated with the creekbank, which acts to promote Spartina alterniflora growth, and the rate of development of the marsh. The marsh becomes functionally more mature in areas where the production is higher In addition, the hydrological processes within the creek itself, which are associated with the rising and falling of the tides, act to accelerate the development of the marsh by preventing the loss of nutrients and particulates. In this fashion, a small chronosequence is developed at the edge of the creek, and the marsh spreads from the creekbank outwards
In using a chronosequence of marshes to estimate rates of development, we have assumed that all of the marshes are following the same developmental trajectory. It is evident that this assumption has been violated in 2 ways. First, as we have discussed several times previously, geomorphology is the main factor that structures marsh function. The marshes in this study are at different elevations, which we presume is related to the ecological age of the marsh and which also undoubtedly has an effect on the rate of development of the marsh after vegetation is present. We therefore cannot assume that all of these marshes are developing at the same rate.

A second potential violation of our 'space-for-time' assumption comes forward in a comparison of our 2 youngest creeks, Y1 and Y2. Although these 2 marshes have approximately the same ecological age, elevation, and local geomorphology, it is evident that there are other factors controlling the relative rates of development. Y2 has much lower Spartina alterniflora biomass than all of the other marshes. In contrast, Y1 has higher biomass and appears to be 'aging' more rapidly. The primary difference between these 2 sites was the elevated porewater salinity at $Y 2(26.8 \pm 0.8 \mathrm{ppt}$ at $\mathrm{Y} 1 \mathrm{vs}$ $36.6 \pm 0.4 \mathrm{ppt}$ at $\mathrm{Y} 2$ ), which has a detrimental effect on $S$. alterniflora growth (Phleger 1971). This substantial variation in salinity is derived from a significant difference in groundwater influx between the 2 marshes, which results from the geomorphological differences between the marsh/upland complex within which each creek resides. Y1 receives a freshwater influx from a pond situated in the upland, while $\mathrm{Y} 2$ is down-gradient from a salt flat and receives little to no freshwater influx (Tyler 1997). In the case of Y2, it appears that the salinity, as moderated by the regional morphology of the marsh/upland complex (arrows 16 and 17, Fig. 6), is the dominant factor controlling the rate of development. That $\mathrm{Y} 2$ is on a different developmental trajectory than the other marshes in this study is also evidenced by the fact that it has significantly different factor scores for PC2.

\section{Conclusions and management implications}

Several predictable trends take place along our chronosequence. The sediments grade from a sandy substrate to a more highly organic, muddy substrate. The porewater becomes enriched in nutrients and the sulfide concentration increases. The plants are taller and more robust, and they exhibit different reproductive patterns and tissue element composition. Similar trends are seen as the creekbank is approached, such that within each young marsh the areas in the vicinity of the creek are relatively more mature than those dis- 
tant from the creek. However, we have also demonstrated that not all marshes are created equal and that the developmental trajectory can be determined by the larger landscape properties of the marsh/upland complex.

Many mitigation projects fail because of a lack of communication between the engineers who design and restore wetlands and the ecologists who study them. In an evaluation of the function of a restored marsh, Moy \& Levin (1991) and Minello et al. (1994) suggested that increased creek frontage may increase marsh utilization by macrofauna. However, inappropriate creek construction can cause failure of restoration efforts (Haltiner et al. 1997). This study suggests that in a naturally developing marsh the creekbank. plays an important role in enhancing both primary production and the rate of development. If, indeed, tidal creeks do accelerate development, restoration efforts should be designed such that the ratio of creek bank to marsh interior maximizes the rate of marsh development. This type of 'ecotechnological' method for escalating marsh development is important in achieving early functional equivalency of created marshes (Zedler 1992).

Acknowledgements. Financial and logistical support for this work was provided by the Virginia Coast Reserve Long Term Ecological Research Project (National Science Foundation Grant No. DEB-9411974). Additional support came from the William H. Bannon Fund. Invaluable field and lab assistance was provided by J. Walsh, B. Silliman, K. Loomis, J. Spitler, J. Tomkins, S. Wear and V. Turekian. We are grateful to D. Osgood, J. Walsh and 3 anonymous reviewers, who provided helpful comments during the revision of the original manuscript.

\section{LITERATURE CITED}

Agosta K (1985) The effect of tidally induced changes in the creekbank water table on pore water chemistry. Estuar Coast Shelf Sci 21:389-400

Anderson IC, Tobias CR, Neikirk BB, Wetzel RL (1997) Development of a process-based nitrogen mass balance for a Virginia (USA) salt marsh: implications for net DIN flux. Mar Ecol Prog Ser 159:13-27

Aziz S, Nedwell DB (1986) The nitrogen cycle of an East Coast, U.K. salt marsh: II Nitrogen fixation, nitrification, denitrification, tidal exchange. Estuar Coast Shelf Sci 22: 689-704

Badger CJ, Kellam R (1989) The barrier islands: a photographic history of life on Hog, Cobb, Smith, Cedar, Parramore, Metompkin, \& Assateague. Stackpole Books, Harrisburg, PA.

Barnes RSK, Sattelle DB, Everton IJ, Nicholas W, Scott DH (1976) Intertidal sands and interstitial fauna associated with different stages of salt-marsh development. Estuar Coast Mar Sci 4:497-511

Bertness MD (1991) Zonation of Spartina patens and Spartina alterniflora in a New England salt marsh. Ecology 72: $138-148$
Brinson MM, Rheinhardt R (1996) The role of reference wetlands in functional assessment and mitigation. Ecol Appl 6:69-76

Brinson MM, Christian RR, Blum LK (1995) Mulitple states in the sea-level induced transition from terrestrial forest to estuary. Estuaries 18:648-659

Broome SW, Seneca ED, Woodhouse WW Jr (1986) Long-term growth and development of transplants of the salt-marsh grass Spartina alterniflora. Estuaries 9:63-74

Brower JE, Zar JH (1984) Field and laboratory methods for general ecology. Brown, Dubuque, IA

Cammen LM (1976a) Accumulation rate and turnover time of organic carbon in a salt marsh sediment. Limnol Oceanogr 20:1012-1015

Cammen LM (1976b) Macroinvertebrate colonization of Spartina marshes artificially established on dredge spoil. Estuar Coast Mar Sci 4:357-372

Chambers RM, Odum WE (1990) Porewater oxidation, dissolved phosphate and the iron curtain: iron-phosphorus relations in tidal freshwater marshes. Biogeochemistry 10 : $37-52$

Chapman VJ (1960) Salt marshes and salt deserts of the world. L Hill, London

Childers DL (1994) Fifteen years of marsh flumes: a review of marsh-water column interactions in southeastern USA estuaries. In: Mitsch WJ (ed) Global wetlands: old world and new. Elsevier Science, New York, p 277-293

Childers DL, Cofer-Shabica S, Nakashima L (1993) Spatial and temporal variability in marsh-water column interactions in a southeastern USA salt marsh estuary. Mar Ecol Prog Ser 95:25-38

Cline JD (1969) Spectrophotometric determination of hydrogen sulfide in natural waters. Limnol Oceanogr 14: $454-458$

Cowles HC (1901) The physiographic ecology of Chicago and vicinity; a study of the origin, development, and classification of plant societies. Bot Gaz 31:145-182

Craft CB, Broome SW, Seneca ED (1988) Nitrogen, phosphorus and organic carbon pools in natural and transplanted marsh soils. Estuaries 11:272-280

Craft CB, Broome SW, Seneca ED (1989) Exchange of nitrogen, phosphorus and organic carbon between transplanted marshes and estuarine waters. J Environ Qual 18: 206-211

Currin CA, Paerl HW (1998) Epiphytic nitrogen fixation associated with standing dead shoots of smooth cordgrass, Spartina alterniflora. Estuaries 21:108-117

Currin CA, Joye SB, Paerl HW (1996) Diel rates of $\mathrm{N}_{2}$ fixation and denitrification in a transplanted Spartina alterniflora marsh: implications for N-flux dynamics. Estuar Coast Shelf Sci 42:597-616

Dame RF, Gardner LR (1993) Nutrient processing and the development of tidal creek ecosystems. Mar Chem 43: $175-183$

Dame R, Childers D, Koepfler E (1992) A geohydrologic continuum theory for the spatial and temporal evolution of marsh-estuarine ecosystems. Neth $J$ Sea Res 30:63-72

de Leeuw J, de Munck W, Olff H, Bakker JP (1993) Does zonation reflect the succession of salt-marsh vegetation? A comparison of an estuarine and a coastal bar island marsh in The Netherlands. Acta Bot Neerl 42:435-445

Drury WH, Nisbet ICT (1973) Succession. J Arnold Arbor Harv Univ 54:331-368

Fitch GM (1991) The role of overwash on Hog Island. Master's thesis, University of Virginia, Charlottesville

Freeze RA, Cherry JA (1979) Groundwater Prentice Hall, Englewood Cliffs, NJ 
French JR, Stoddart DR (1992) Hydrodynamics of salt marsh creek systems: implications for marsh morphological development and material exchange. Earth Surf Proc Landforms 17:235-252

Frey RW, Basan PB (1978) Coastal salt marshes. In: Davis RA Jr (ed) Coastal sedimentary environments. Springer-Verlag, New York, p 101-159

Garofalo D (1980) The influence of wetland vegetation on tidal stream channel migration and morphology. Estuaries $3: 258-270$

Godfrey PJ, Godfre: :1M (1976) Barrier island ecology of Cape Lookout national seashore and vicinity, North Carolina. National Park Service Monograph Series No. 9 Washington, DC

Grasshoff K, Ehrhardt M, Kremling K (1983) Methods of seawater analysis, Verlag Chemie, Weinheim

Gray AJ (1992) Saltmarsh plant ecology: zonation and succession revisited. In: Allen JRL, Pye K (eds) Saltmarshes: morphodynamics, conservation and engineering significance. Cambridge University Press, Cambridge, p 63-79

Haltiner J, Zedler JB, Boyer KE, Williams GD, Callaway JC (1997) Influence of physical processes on the design, functioning and evolution of restored tidal wetlands in California (USA). Wetlands Ecol Manage 4:73-91

Harvey JW, Germann PF, Odum WE (1987) Geomorphological control of subsurface hydrology in the creekbank zone of tidal marshes. Estuar Coast Shelf Sci 25:677-691

Havens KJ, Varnell LM, Bradshaw JG (1995) An assessment of ecological conditions in a constructed tidal marsh and two natural reference tidal marshes in coastal Virginia. Ecol Eng 4:117-141

Hayden BP, Dueser RD, Callahan JT, Shugart HH (1991) Long-term research at the Virginia Coast Reserve: modeling a highly dynamic environment. BioSci 41:310-318

Howes BL, Goehringer DD (1994) Porewater drainage and dissolved organic carbon and nutrient losses through the intertidal creekbanks of a New England salt marsh. Mar Ecol Prog Ser 1.14:289-301

Jones MN (1984) Nitrate reduction for shaking with cadmium: alternative to cadmium columns. Water Res 18:643-646

King GM, Klug MJ, Wiegert RG, Chalmers AG (1982) Relation of soll water movement and sulfide concentration to Spartina alterniflora production in a Georgia salt marsh. Science 218:61-63

Knighton AD, Woodroffe CD, Mills K (1992) The evolution of tidal creek networks, Mary River, Northern Australia. Earth Surf Proc Landforms 17:167-190

Langis R, Zalejko M, Zedler JB (1991) Nitrogen assessments in a constructed and a natural salt marsh of San Diego Bay. Ecol Appl 1:40-51

Levin LA, Talley D, Thayer G (1996) Succession of macrobenthos in a created salt marsh. Mar Ecol Prog Ser 141: $67-82$

Lindau CW. Hossner LR (1981) Substrate characterization of an experimental marsh and three natural marshes. Soil Sci Soc Am J 45:1171-1176

Melvin S, Webb J (1998) Differences in the avian communities of natural and created Spartina alterniflora salt marshes. Wetlands 18:59-69

Minello TJ, Webb JW (1997) Use of natural and created Spartina alterniflora salt marshes by fishery species and other aquatic fauna in Galveston Bay, Texas, USA. Mar Ecol Prog Ser 151:165-179

Minello TJ, Zimmerman RJ (1992) Utilization of natural and transplanted Texas salt marshes by fish and decapod crus. taceans. Mar Ecol Prog Ser 90:273-285

Minello TJ, Zimmerman RJ, Medina R (1994) The importance of edge for natant macrofauna in a created salt marsh Wetlands 1.4:184-198

Mitsch WJ, Gosselink JG (1993) Wetlands Van Nostrand Reinhold, New York

Mitsch WJ, Wilson RF (1996) Improving the success of wetland creation and restoration with know-how, time, and self-design. Ecol Appl 6:77-83

Moy LD, Levin LA (1991) Are Spartina marshes a replaceable resource? A functional approach to evaluation of marsh creation efforts. Estuaries 14:1-16

Nuttle WK (1988) The extent of lateral water movement in the sediments of a New England salt marsh. Water Resour Res 24:2077-2085

Nuttle WK, Hemond HF (1988) Salt marsh hydrology: implications for biogeochemical fluxes to the atmosphere and estuaries. Global Biogeochem Cycles 2:91-114

Odum EP (1969) The strategy of ecosystem development. Science 164:262-270

Olson JS (1958) Rates of succession and soil changes on southern Lake Michigan sand dunes. Bot Gaz 119 : $125-170$

Osgood DT, Zieman JC (1993a) Factors controlling aboveground Spartina alterniflora (smooth cordgrass) tissue element composition and production in different-age barrier island marshes. Estuaries 16:815-826

Osgood DT, Zieman JC (1993b) Spatial and temporal patterns of substrate physico-chemical parameters in differentaged barrier island marshes. Estuar Coast Shelf Sci 37 $421-436$

Osgood DT, Zieman JC (1998) The influence of subsurface hydrology on nutrient supply and smooth cordgrass (Spartina alterniflora) production in a developing barrier island marsh. Estuaries 21:767-783

Osgood DT, Santos MCFV, Zieman JC (1995) Sediment physico-chemistry associated with natural marsh development on a storm-deposited sand flat. Mar Ecol Prog Ser 120:271-283

Otte ML, Morris JT (1994) Dimethylsulphoniopropionate (DMSP) in Spartina alterniflora Loisel. Aquat Bot 48: $239-259$

Pestrong $R$ (1965) The development of drainage patterns on tidal marshes. Stanford Univ Publ Geol Sci 10:1-87

Pethick JS (1992) Saltmarsh geomorphology. In: Allen JRL, Pye K (eds) Saltmarshes: morphodynamics, conservation and engineering significance. Cambridge University Press, Cambridge, p 41-62

Phleger CF (1971) Effect of salinity on growth of a salt marsh grass. Ecology 52:908-911

Pickett STA (1991) Space-for-time substitution as an alternative to long-term studies. In: Likens GE (ed) Long-term studies in ecology: approaches and alternatives. SpringerVerlag, New York, p 110-135

Piehler MF, Currin CA, Cassanova R, Paerl HW (1998) Development and $\mathrm{N}_{2}$-fixing activity of the benthic microbial community in transplanted Spartina alterniflora marshes in North Carolina. Restor Ecol 6:290-296

Redfield AC (1972) Development of a New England salt marsh. Ecol Monogr 42:201-237

Reed DJ (1988) Sediment dynamics and deposition in a retreating coastal marsh. Estuar Coast Shelf Sci 26:67-79

Roozen AJM. Westhoff $V$ (1985) A study on long-term saltmarsh succession using permanent plots. Vegetatio 61 $23-32$

Sacco JN, Seneca ED. Wentworth TR (1994) InfaunaI. community development of artificially established salt marshes in North Carolina. Estuaries 17:489-500

Seneca ED, Broome SW, Woodhouse WW Jr, Cammen LM, 
Lyon JT IIl (1976) Establishing Spartina alterniflora marsh in North Carolina. Environ Conserv 3:185-188

Shelford VE (1911) Ecological succession, II. Pond fishes. Biol Bull 21:127-151

Shi Z, Lamb HF, Collin RL (1995) Geomorphic change of saltmarsh tidal creek networks in the Dyfi Estuary, Wales. Mar Geol 128:73-83

Simenstad CA, Thom RM (1996) Functional equivalency trajectories of the restored Gog-Le-Hi-Te estuarine wetland. Ecol Appl 6:38-56

Stewart JQ (1962) The great Atlantic coast tides of 5-8 March 1962. Weatherwise, June 1962, p 117-120

Stumpf RP (1983) The process of sedimentation on the surface of a salt marsh. Estuar Coast Shelf Sci 17:495-508

Thompson SP, Paerl HW, Go MC (1995) Seasonal patterns of nitrification and denitrification in a natural and a restored salt marsh. Estuaries 18:399-408

Tyler AC (1997) Geomorphological and hydrological controls on pattern and process in a developing barrier island salt marsh. Master's thesis, University of Virginia, Charlottesville

Underwood GJC (1997) Microalgal colonization in a saltmarsh restoration scheme. Estuar Coast Shelf Sci 44: $471-481$

Editorjal responsibility: Gordon Thayer (Contributing Editor), Beaufort, North Carolina, USA
Valiela I., Teal JM, Duesser WG (1978) The nature of the growth forms in the salt marsh grass Spartina alterniflora. Am Nat 112:461-470

Vitousek PM, Reiners WA (1975) Ecosystem succession and nutrient retention: a hypothesis. BioSci 25:376-381

Walsh JP (1998) Low marsh succession along an over-wash salt marsh chronosequence. PhD dissertation, University of Virginia, Charlottesville

Wiegert RG, Chalmers AG, Randerson PF (1983) Productivity gradients in salt marshes: the response of Spartina alterniflora to experimentally manipulated soil water movement. Oíkos 41:1-6

Wolaver TG, Spurrier JD (1988) Carbon transport between a euhaline vegetated marsh in South Carolina and the adjacent tidal creek: contributions via tidal inundation, runoff and seepage. Mar Ecol Prog Ser 42:53-62

Wolaver TG, Dame RG, Spurrier JD, Miller AB (1988) Sediment exchange between a euhaline salt marsh in South Carolina and the adjacent tidal creek. J Coast Res 4:17-26

Zedler JB (1992) Restoring cordgrass marshes in southern California. In: Thayer GW (ed) Restoring the nation's marine environment. Maryland Sea Grant College, College Park, MD, p 7-51

Submitted: April 15, 1998; Accepted: November 12, 1998 Proofs received from author(s): April 16, 1999 